\title{
Measurements for Natural Radioactive Materials at the East $\&$ West banks of The River Nile
}

\author{
Mohammed Aidarous El-Tayep, Kh. M. Haroun \\ Department of Physics, Faculty of Education, Al-Zaiem Al-Azhari University, Om Durman, Sudan
}

Email address:

aydrous2007@gmail.com (M. A. El-Tayep)

\section{To cite this article:}

Mohammed Aidarous El-Tayep, Kh. M. Haroun. Measurements for Natural Radioactive Materials at the East \& West banks of The River Nile. Science Journal of Analytical Chemistry. Vol. 5, No. 4, 2017, pp. 56-65. doi: 10.11648/j.sjac.20170504.12

Received: April 20, 2017; Accepted: May 8, 2017; Published: July 26, 2017

\begin{abstract}
Soil samples were collected along the East and West banks of the River Nile region starting from Bait Al-mal in the West side and the second East bank of the River Nile Shambat. Gamma radiation measurements were performed using high resolution HPGe detector with low background PC multichannel spectrometer. The gamma measurements of the soil revealed the presence of the natural long-lived radioisotopes ${ }^{238} \mathrm{U},{ }^{232} \mathrm{Th}$ and ${ }^{40} \mathrm{~K}$. The ranges of their activity concentrations were $3.32 \pm 1.1 \sim 6.3 \pm 2.1 \mathrm{Bqkg}^{-1}, 5.61 \pm 1.7 \sim 10.76 \pm 2.13 \mathrm{Bqkg}^{-1}$ and $180 \pm 7.77 \sim 291 \pm 11.6 \mathrm{Bqkg}^{-1}$ 'respectively'. The other factors controlling the distribution of the detected natural radioisotopes have been discussed. Absorbed dose rates have been calculated for each location with range $15.27 \pm 0.82 \sim 21.07 \pm 1.53 \mathrm{nGyh}^{-1}$. Also, the estimated activity utilization indexes have been presented. The ratios between the detected radioisotopes have been calculated.
\end{abstract}

Keywords: Uranium, Thorium, Potassium, Absorbed Dose Rate, Radiation Exposure

\section{Introduction}

There are two kinds of radiation according to their origin: natural and artificial radiation. Natural radiation comes from cosmic rays from outer space and naturally occurring radioactive materials (NORMs) that exist in food, air and our natural habitat while exposure in medical practice mostly due to diagnostic X-rays, contributes the largest fraction of human's exposure to artificial radiation. About $90 \%$ of human radiation exposures arise from natural sources [3].

Significant naturally occurring radionuclides present in the soil are ${ }^{238} \mathrm{U},{ }^{232} \mathrm{Th}$ and ${ }^{40} \mathrm{~K}[4]$.

These radionuclides are not uniformly distributed hence, the knowledge of their distribution in soil plays an important role in radiation protection.

Soil not only acts as a source of continuous radiation exposure to humans but also as a medium of migration for transfer of radionuclides to biological systems [5]. Hence, the basic indicator of radiological contamination in the environment is the soil [6]. The understanding of the decay chain where series of stepwise decay in terms of half-lives of nuclei of unstable radionuclides lead to stable states in form of other nuclides is very paramount. Alpha $(\alpha)$ and beta $(\beta)$ particles are still emitting with the gamma but their travel distance in the air is limited while gamma $(\gamma)$ radiation is emitted. High levels of uranium and thorium and their decay products in rock and soil are the main sources of high natural background radiation. There is a continuous bombardment of human and his environment by these (radionuclides) ionizing radiations [7]. The long term exposure to uranium and its daughters such as radium and radon through inhalation has several health effects such as chronic lung diseases, acute leucopoenia, anemia and necrosis of the mouth. Radium causes bone, cranial and nasal tumors. Thorium exposure can cause lung, pancreas, hepatic, bone, kidney cancers and leukemia [8].

Therefore, gamma dose rates and radionuclides activity concentrations should be monitored because of their health implications.

The Nile River is the longest river in the world. In ancient times, the Nile River flooded annually, caused by rains in central Africa and in Ethiopian highlands carrying great quantities of silt in its water. [12].

The Nile River has supported many civilizations of Egypt and Sudan throughout history and continues to play a vital role in supplying precious water for drinking, irrigation, and 
industry to the people of the Sudan. The Nile River plays an essential role in Sudanese life; it is the life line of Egypt and Sudan, the study of the natural radioactivity of the coasts of the River Nile is very important, and the assessment of natural dose rates will be of some interest to regional health.

The Nile is a major north-owing river in north eastern Africa. It is $6650 \mathrm{~km}$ long. It runs through the 10 countries of Sudan, South Sudan, Burundi, Rwanda, the Democratic Republic of the Congo, Tanzania, Kenya, Ethiopia, Uganda, and Egypt. During the last decades, there has been an increasing interest in the study of radioactivity in River Nile soil $[9,10,11]$.

\section{Materials and Methods}

\subsection{Sampling}

A total number of 30 surface soil (dry and out of the Nile water) samples were collected along the East and West banks of the River Nile region from 30 successive locations at a chosen point, data from Global Positioning System (GPS) were used for tracking the data recorded starting from Bait Al-mal in the West $\left(15^{\circ} 39^{\prime} 0.20^{\prime \prime} \mathrm{N} \sim 32^{\circ} 30^{\prime} 25.30^{\prime \prime} \mathrm{E}\right)$ to the

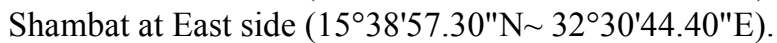

The samples locations are listed in Table 1 and showed in(Figure. 1)and (Figure 2) The study area was divided into
Two sections First the East bank and second West bank of the River Nile.

\subsection{Study Area Description}

The study area is located on the banks of the Nile River north of Khartoum, starting from Bait Al-mal in the West $\left(15^{\circ} 39^{\prime} 0.20^{\prime \prime} \mathrm{N} \sim 32^{\circ} 30^{\prime} 25.30^{\prime \prime} \mathrm{E}\right)$ to the Shambat at East side $\left(15^{\circ} 38^{\prime} 57.30^{\prime \prime} \mathrm{N} \sim 32^{\circ} 30^{\prime} 44.40^{\prime \prime} \mathrm{E}\right)$. This area was chosen because it is an agricultural area and provide the Khartoum markets with the necessary vegetables and the agricultural land at two sides are used fertilizers from originally from Phosphate.

The significance of the current study relies on its contribution to the efforts being done to generate a radiation map for Sudan and on the targeted area, The River Nile which is of great importance due to the heavy agricultural activities involved. Level of natural radioactivity in surface soil samples collected along the east and west banks of the River Nile will be evaluated using high resolution HPGe detector. The study measures the activity concentrations of ${ }^{238} \mathrm{U},{ }^{232} \mathrm{Th}$ and ${ }^{40} \mathrm{~K}$ across all of the soil samples. The radiological hazard to humans due to the radioactivity arising from radionuclides contained in soils samples is to be assessed and the absorbed dose rates based on soil radioactivity is to be estimated.

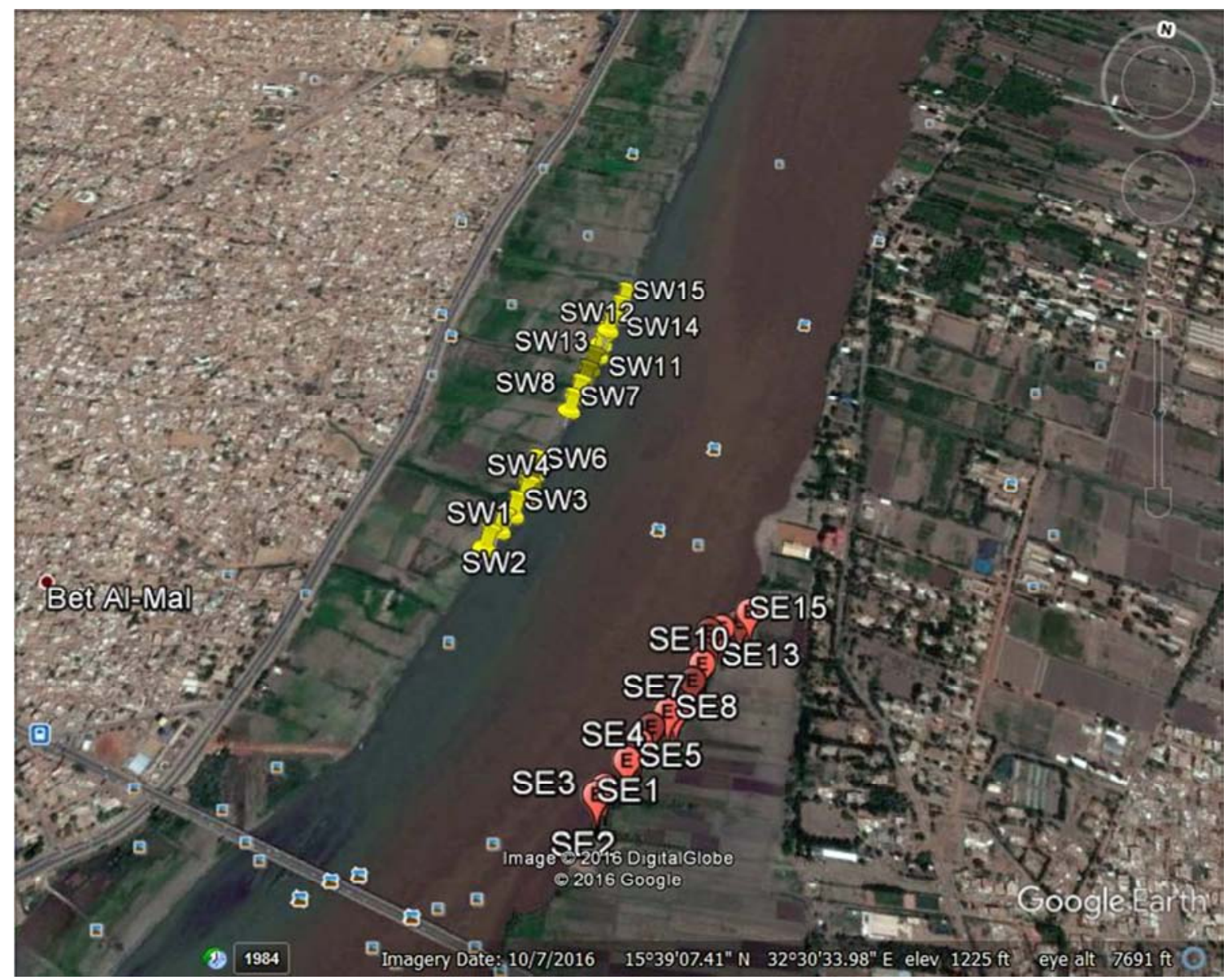

Figure 1. Map for samples'location. 


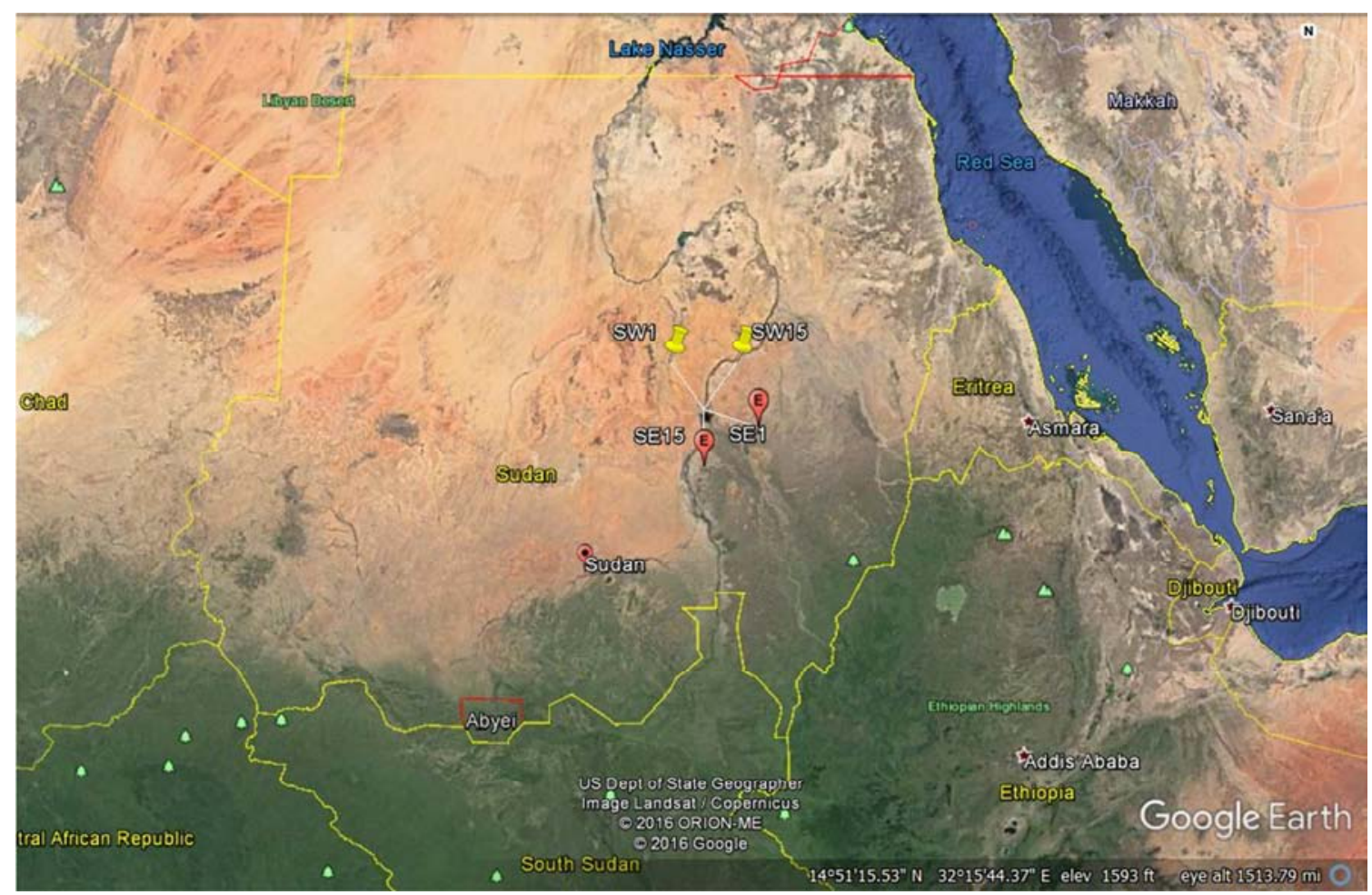

Figure 2. Site area under study for a map of Sudan.

Table 1. Sample codes, locations and types.

\begin{tabular}{|c|c|c|c|c|c|}
\hline Code no. & N (Degrees) & E (Degrees) & Code no & N (Degrees) & E (Degrees) \\
\hline SW1 & $15^{\circ} 39^{\prime} 0.20^{\prime \prime N}$ & $32^{\circ} 30^{\prime} 25.30^{\prime \prime} \mathrm{E}$ & SE1 & $15^{\circ} 38^{\prime} 41.90^{\prime \prime} \mathrm{N}$ & $32^{\circ} 30^{\prime} 35.40^{\prime \prime} \mathrm{E}$ \\
\hline SW2 & $15^{\circ} 39^{\prime} 1.60 " \mathrm{~N}$ & $32^{\circ} 30^{\prime} 26.00^{\prime \prime} \mathrm{E}$ & SE2 & $15^{\circ} 38^{\prime} 44.40^{\prime \prime} \mathrm{N}$ & $32^{\circ} 30^{\prime} 36.30^{\prime \prime} \mathrm{E}$ \\
\hline SW3 & $15^{\circ} 39^{\prime} 2.90^{\prime \prime} \mathrm{N}$ & $32^{\circ} 30^{\prime} 26.70^{\prime \prime} \mathrm{E}$ & SE3 & $15^{\circ} 38^{\prime} 44.90^{\prime \prime} \mathrm{N}$ & $32^{\circ} 30^{\prime} 36.70^{\prime \prime} \mathrm{E}$ \\
\hline SW4 & $15^{\circ} 39^{\prime} 4.30^{\prime \prime N}$ & $32^{\circ} 30^{\prime} 27.20^{\prime \prime} \mathrm{E}$ & SE4 & $15^{\circ} 38^{\prime} 46.70^{\prime \prime} \mathrm{N}$ & $32^{\circ} 30^{\prime} 37.80^{\prime \prime} \mathrm{E}$ \\
\hline SW5 & $15^{\circ} 39^{\prime} 5.60^{\prime \prime} \mathrm{N}$ & $32^{\circ} 30^{\prime} 27.40^{\prime \prime} \mathrm{E}$ & SE5 & $15^{\circ} 38^{\prime} 47.80^{\prime \prime} \mathrm{N}$ & $32^{\circ} 30^{\prime} 38.40^{\prime \prime E}$ \\
\hline SW6 & $15^{\circ} 39^{\prime} 6.40^{\prime \prime} \mathrm{N}$ & $32^{\circ} 30^{\prime} 27.50^{\prime \prime} \mathrm{E}$ & SE6 & $15^{\circ} 38^{\prime} 48.90^{\prime \prime} \mathrm{N}$ & $32^{\circ} 30^{\prime} 39.00^{\prime \prime} \mathrm{E}$ \\
\hline SW7 & $15^{\circ} 39^{\prime} 11.90^{\prime \prime} \mathrm{N}$ & $32^{\circ} 30^{\prime} 29.10^{\prime \prime} \mathrm{E}$ & SE7 & $15^{\circ} 38^{\prime} 50.00^{\prime \prime} \mathrm{N}$ & $32^{\circ} 30^{\prime} 39.90^{\prime \prime} \mathrm{E}$ \\
\hline SW8 & $15^{\circ} 39^{\prime} 13.20^{\prime \prime} \mathrm{N}$ & $32^{\circ} 30^{\prime} 29.40^{\prime \prime} \mathrm{E}$ & SE8 & $15^{\circ} 38^{\prime} 50.10^{\prime \prime} \mathrm{N}$ & $32^{\circ} 30^{\prime} 40.40^{\prime \prime} \mathrm{E}$ \\
\hline SW9 & $15^{\circ} 39^{\prime} 14.50^{\prime \prime} \mathrm{N}$ & $32^{\circ} 30^{\prime} 29.70^{\prime \prime} \mathrm{E}$ & SE9 & $15^{\circ} 38^{\prime} 52.20^{\prime \prime} \mathrm{N}$ & $32^{\circ} 30^{\prime} 41.20^{\prime \prime} \mathrm{E}$ \\
\hline SW10 & $15^{\circ} 39^{\prime} 15.80^{\prime \prime} \mathrm{N}$ & $32^{\circ} 30^{\prime} 30.00^{\prime \prime} \mathrm{E}$ & SE10 & $15^{\circ} 38^{\prime} 53.40^{\prime \prime} \mathrm{N}$ & $32^{\circ} 30^{\prime} 41.70 " \mathrm{E}$ \\
\hline SW11 & $15^{\circ} 39^{\prime} 17.10^{\prime \prime} \mathrm{N}$ & $32^{\circ} 30^{\prime} 30.40^{\prime \prime} \mathrm{E}$ & SE11 & $15^{\circ} 38^{\prime} 53.90^{\prime \prime} \mathrm{N}$ & $32^{\circ} 30^{\prime} 41.80^{\prime \prime} \mathrm{E}$ \\
\hline SW12 & $15^{\circ} 39^{\prime} 18.20^{\prime \prime} \mathrm{N}$ & $32^{\circ} 30^{\prime} 30.50^{\prime \prime} \mathrm{E}$ & SE12 & $15^{\circ} 38^{\prime} 55.60^{\prime \prime} \mathrm{N}$ & $32^{\circ} 30^{\prime} 41.90^{\prime \prime} \mathrm{E}$ \\
\hline SW13 & $15^{\circ} 39^{\prime} 19.50^{\prime \prime} \mathrm{N}$ & $32^{\circ} 30^{\prime} 30.80^{\prime \prime} \mathrm{E}$ & SE13 & $15^{\circ} 38^{\prime} 55.90^{\prime \prime} \mathrm{N}$ & $32^{\circ} 30^{\prime} 42.70^{\prime \prime} \mathrm{E}$ \\
\hline SW14 & $15^{\circ} 39^{\prime} 20.90^{\prime \prime} \mathrm{N}$ & $32^{\circ} 30^{\prime} 31.20^{\prime \prime} \mathrm{E}$ & SE14 & $15^{\circ} 38^{\prime} 56.50^{\prime \prime} \mathrm{N}$ & $32^{\circ} 30^{\prime} 43.80^{\prime \prime} \mathrm{E}$ \\
\hline SW15 & $15^{\circ} 39^{\prime} 22.20^{\prime \prime} \mathrm{N}$ & $32^{\circ} 30^{\prime} 31.50^{\prime \prime} \mathrm{E}$ & SE15 & $15^{\circ} 38^{\prime} 57.30^{\prime \prime} \mathrm{N}$ & $32^{\circ} 30^{\prime} 44.40^{\prime \prime} \mathrm{E}$ \\
\hline
\end{tabular}

\subsection{Radioactivity Measurements}

The soil samples were collected from the upper layer at depth $0-30 \mathrm{~cm}$ using plastic cup and then placed in plastic bags and prepared. These were first placed a dry area for few minutes and then placed in an oven to be heated at a temperature of $60^{\circ} \mathrm{C}$ for 24 hours. This was to remove all moisture found in the samples. The samples were then sieved using $2 \mathrm{~mm} 500 \mu \mathrm{m}$ mesh to differentiate particle size. A Marinelli beaker (size $500 \mathrm{ml}$ ) was used to seal the soil samples, weighted and labelled. The samples were stored for at least one whole month to reach secular equilibrium. The samples filled in the beaker are of the same volume and are assumed to be homogenous with respect to parameter to be measured. Marinelli beakers are chemically resistant polypropylene, light weight and seamlessness which eliminate leaks. They are used for gamma-spectral analysis because of their high counting efficiencies and because they minimize gamma-ray attenuation. The details of the sample characteristics are shown in Table 2 [40].

Table 2. Show sealing date at weights for two samples as ex.

\begin{tabular}{llll}
\hline Sample ID & Sealing Date & $\begin{array}{l}\text { Beaker } \\
\text { Weight (g) }\end{array}$ & Sample Weight (g) \\
\hline SE1 & 12th March 2014 & 83.61 & 1250.61 \\
SW1 & 30th March 2014 & 83.45 & 1250.73 \\
\hline
\end{tabular}

For gamma analysis, the soil samples were placed directly over the detector. The measured activity concentrations were presented as $\mathrm{Bqkg}^{-1}$.

The $(1460.83 \mathrm{keV})$ gamma transition was used to determine the concentration of ${ }^{40} \mathrm{~K}$ in different samples. The gamma transitions used to determine the concentrations of 
${ }^{238} \mathrm{U}$ and ${ }^{232} \mathrm{Th}$ were listed in Table 3.

The gamma ray measurements were performed with a low background spectrometer with PC multichannel analyzer and HPGe detector high resolution.

The details of the coaxial hyper-pure germanium detector (HPGe) and the parameters used for this experimental project are as follows:

1. Model name: GCW2021

2. Cryostat Model: 7500-RDC-4ULB

3. Operating Voltage: 3000 Volt

4. Serial number: 06308

5. Preamplifier Model: 2002C

6. Standard calibration Sources use are ${ }^{152} \mathrm{Eu},{ }^{226} \mathrm{Ra},{ }^{232} \mathrm{Th}$ and NG3

\subsection{Quality Control}

Three types of calibrations were carried out for HPGe detector. These are energy, resolution and efficiency calibrations. Efficiency calibration was performed using ${ }^{152} \mathrm{Eu}$ standard source. ${ }^{152} \mathrm{Eu}$ was manufactured by Amersham International plc. Precision and accuracy were checked by parallel measurements of IAEA inter comparison soil samples; IAEA-300 and IAEA-315. In order to determine the background due to the existence of natural radionuclides in the environment, an empty polyethylene container with the same geometry and the same measuring conditions as for the samples, was used. The uncertainties in the calibration of the peak areas of these photo peaks were within $\pm 2 \%$.

\subsection{Energy Calibration}

The initial energy calibration was performed using a standard source $\left({ }^{152} \mathrm{Eu}\right)$ with an activity of $2.549 \mathrm{kBq}$. Source is placed on the detector for a preset time and counts for seconds. The energies of ${ }^{152} \mathrm{Eu}$ source, ranging from 121.78 , $244.96,344.27,778.90,964.07$ and $1408 \mathrm{keV}$ were used to calibrate the detector. The linear relationship between energy and channel is shown in Figure 2.1. The displayed equation on the plot is used to find other peaks that do not belong to standard source ${ }^{152} \mathrm{Eu}$. The equation relates to the gamma energy at any given channel $x$. The spectra energy lines corresponding to the counts are shown in Figure 3.

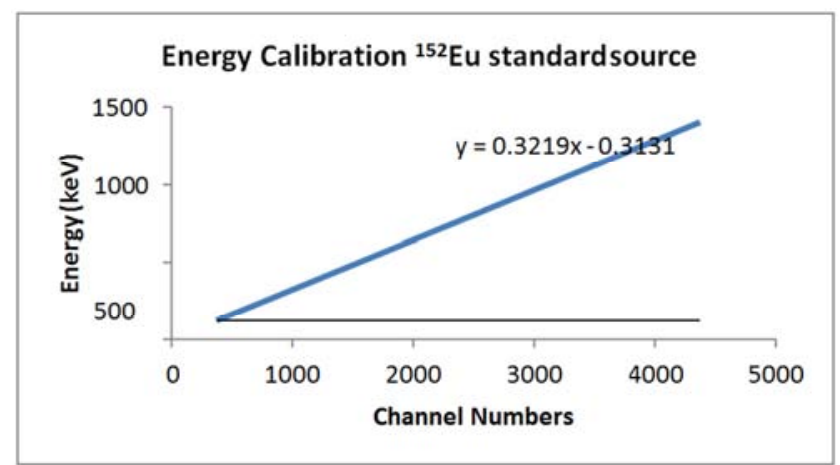

Figure 3. Linear relationship between channel numbers corresponding to Energy.

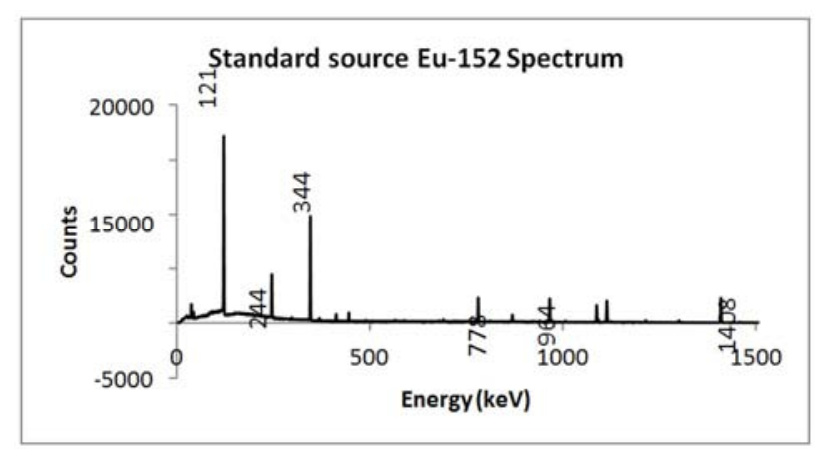

Figure 4. Spectra lines from the 152Eu calibration source.

\subsection{Efficiency Calibration}

In efficiency calibration, four standard sources ${ }^{226} \mathrm{Ra},{ }^{232} \mathrm{Th}$, NG3 and ${ }^{152} \mathrm{Eu}$ were used. The gamma ray energy lines ranges from $\sim 100$ to $2.6 \mathrm{MeV}$ were used to analyze the absolute full energy peak detection efficiency. The NG3 source consisting of ${ }^{241} \mathrm{Am},{ }^{57} \mathrm{Co},{ }^{60} \mathrm{Co},{ }^{85} \mathrm{Sr},{ }^{88} \mathrm{Y},{ }^{109} \mathrm{Cd},{ }^{137} \mathrm{Cs},{ }^{139} \mathrm{Ce}$, and ${ }^{203} \mathrm{Hg}$ provided by Hi-tech sources. The values obtained are used to plot the efficiency curve as shown in Figure 5.

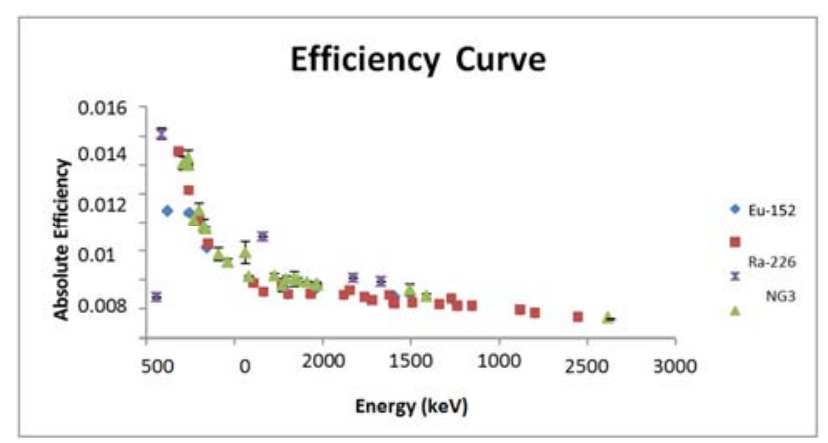

Figure 5. The absolute full-energy peak efficiency measurement using the Standard sources ${ }^{226} \mathrm{Ra},{ }^{232} \mathrm{Th},{ }^{152} \mathrm{Eu}$ and $\mathrm{NG} 3$.

Table 3. Gamma rays and their related isotopes used to calculate the activity concentrations of ${ }^{238} \mathrm{U},{ }^{232}$ Th and ${ }^{40} \mathrm{~K}$.

\begin{tabular}{llll}
\hline \multirow{2}{*}{ Nuclide } & Half-life & Gamma ray energy & Isotope \\
\cline { 2 - 4 } & (years) & $\mathbf{( k e V )}$ & \\
\hline${ }^{238} \mathrm{U}$ & $4.468 \pm 0.003 \times 10^{9}$ & $63.290 \pm 0.02$ & ${ }^{234} \mathrm{Th},{ }^{234} \mathrm{~Pa}$ \\
& & $295.224 \pm 0.002$ & ${ }^{214} \mathrm{~Pb}$ \\
& & $351.932 \pm 0.002$ & ${ }^{214} \mathrm{~Pb}$ \\
& & $609.312 \pm 0.007$ & ${ }^{214} \mathrm{Bi}$ \\
${ }^{232} \mathrm{Th}$ & $1.405 \pm 0.006 \times 10^{10}$ & $1120.287 \pm 0.01$ & ${ }^{214} \mathrm{Bi}$ \\
& & $338.632 \pm 0.002$ & ${ }^{212} \mathrm{~Pb}$ \\
& & $727.330 \pm 0.009$ & ${ }^{228} \mathrm{Ac}$ \\
& & $968.971 \pm 0.017$ & ${ }^{228} \mathrm{Ac}$ \\
${ }^{40} \mathrm{~K}$ & $1.277 \pm 0.008 \times 10^{9}$ & 1460.83 & $\mathrm{Single}$ \\
\hline
\end{tabular}

Table 4. The ORETICAL Gamma ray exposure rates and gamma dose rate 1 $m$ above a plane and infinite homogeneous soil medium per unit radioelement concentration assuming radioactive equilibrium in the $U$ and Th decay series (IAEA, 1989, IAEA, 1991, Lovborg, 1984).

\begin{tabular}{lll}
\hline \multirow{2}{*}{ Radioelement concentration } & Exposure rate & Dose rate \\
\cline { 2 - 3 } & $(\boldsymbol{\mu R} / \mathbf{h})$ & $\mathbf{( n G y / h )}$ \\
\hline $1 \% \mathrm{~K}$ & 1.505 & 13.078 \\
$1 \mathrm{ppm} \mathrm{U}$ & 0.653 & 5.675 \\
$1 \mathrm{ppm} \mathrm{Th}$ & 0.287 & 2.494 \\
\hline
\end{tabular}


Table 5. The global average annual effective dose from natural radiation sources (UNSCEAR, 1988).

\begin{tabular}{llll}
\hline Source of irradiation & $\begin{array}{l}\text { External } \\
(\mathbf{m S v})\end{array}$ & $\begin{array}{l}\text { Internal } \\
(\mathbf{m S v})\end{array}$ & Total $(\mathbf{m S v})$ \\
\hline $\begin{array}{l}\text { Cosmic rays } \\
\text { Cosmo genic radionuclides }\end{array}$ & $0.410(17)$ & & $0.410(17)$ \\
Natural sources: & & $0.015(1)$ & $0.015(1)$ \\
${ }^{40} \mathrm{~K}$ & $0.150(6)$ & $0.180(7)$ & $0.330(13)$ \\
${ }^{238} \mathrm{U}-$ series & $0.100(4)$ & $1.239(51)$ & $1.339(55)$ \\
${ }^{232} \mathrm{Th}-$ series & $0.160(7)$ & $0.176(7)$ & $0.336(14)$ \\
Total & $0.820(34)$ & $1.616(66)$ & $2.436(100)$ \\
\hline
\end{tabular}

Note: relative values are given in brackets $(\%)$.

\section{Results and Discussion}

\section{1. ${ }^{238} \mathrm{U},{ }^{232} \mathrm{Th}$ and ${ }^{40} \mathrm{~K}$ Activity Concentrations}

The activity concentrations of the detected radionuclides ${ }^{238} \mathrm{U},{ }^{232} \mathrm{Th}$ and ${ }^{40} \mathrm{~K}$ are presented in Table 6 and showed in Figure 6

Elemental concentrations are calculated from measured radiological concentrations in the soil samples. First, the radiological concentration of nuclide $\mathrm{i}, C$, in units of $\mathrm{Bq} \mathrm{kg}^{-1}$ of soil, is calculated using,

$$
\mathrm{C}=\frac{\boldsymbol{c i}}{Y i \cdot M x \cdot \varepsilon i}
$$

where $C i$ is the measured count rate [cts/sec], $Y i$ is the yield of gamma rays per disintegration, $\varepsilon i$ is the efficiency [cts/gamma] of the detector at the energy of the nuclide $\mathrm{i}$ gamma ray, and $M x$ is the dry mass of the soil sample being analyzed.

The activity concentration ranges for ${ }^{238} \mathrm{U},{ }^{232} \mathrm{Th}$ and ${ }^{40} \mathrm{~K}$ were at East side $3.91 \pm 0.44 \sim 5.72 \pm 2.15 \mathrm{Bqkg}^{-1}$ with average $4.5 \pm 1.23 \mathrm{Bqkg}^{-1}, 5.61 \pm 1.7 \sim 10.76 \pm 2.13 \mathrm{Bqkg}^{-1}$ with average $7.8 \pm 1.99 \mathrm{Bqkg}^{-1}$ and $180 \pm 7.77 \sim 291 \pm 11.6 \mathrm{Bqkg}^{-1}$ with average $240.26 \pm 7.9 \mathrm{Bqkg}^{-1}$, 'respectively'. At West side $3.32 \pm 1.1 \sim 6.3 \pm 2.1 \mathrm{Bqkg}^{-1}$ with average $4.7 \pm 1.85 \mathrm{Bqkg}^{-1}$, $6.92 \pm 2.06 \sim 9 \pm 1.3 \mathrm{Bqkg}^{-1}$ with average $7.92 \pm 1.42 \mathrm{Bqkg}^{-1}$ and $197.5 \pm 4.77 \sim 267 \pm 9.68 \mathrm{Bqkg}^{-1}$ with average $231.34 \pm 6.47$ $\mathrm{Bqkg}^{-1}$ 'respectively'.

Table 6. Activity concentrations $\left(B q \mathrm{~kg}^{-1}\right)$ of ${ }^{238} \mathrm{U},{ }^{232} \mathrm{Th}$ and ${ }^{40} \mathrm{~K}$ with their uncertainties, absorbed dose (nGy $\left.\mathrm{h}^{-1}\right)$, in the coasts of the Nile River Soil samples collected from west and east side.

\begin{tabular}{|c|c|c|c|c|c|c|c|c|c|c|}
\hline $\begin{array}{l}\text { sample } \\
\text { code no }\end{array}$ & ${ }^{238} \mathbf{U}$ & ${ }^{232} \mathrm{Th}$ & ${ }^{40} \mathrm{~K}$ & $\begin{array}{l}\text { absorbed } \\
\text { dose }\end{array}$ & ${ }^{238} \mathrm{U} /{ }^{232} \mathrm{Th}$ & ${ }^{232} \mathrm{Th} /{ }^{238} \mathrm{U}$ & ${ }^{232} \mathrm{Th} /{ }^{40} \mathrm{~K}$ & ${ }^{238} \mathbf{U} /{ }^{40} \mathbf{K}$ & $\begin{array}{l}\text { AEDR out } \\
(\mathrm{mSv} / \mathrm{y})\end{array}$ & $\begin{array}{l}\text { AEDR in } \\
(\mathrm{mSv} / \mathrm{y})\end{array}$ \\
\hline SE1 & $5.31 \pm 1.52$ & $10.76 \pm 1.93$ & $277 \pm 9.82$ & $21.07 \pm 1.53$ & 0.5 & 2.02 & 0.04 & 0.02 & 0.026 & 0.10 \\
\hline SE2 & $4.74 \pm 1.32$ & $6.92 \pm 1.2$ & $232 \pm 5.3$ & $16.38 \pm 0.63$ & 0.7 & 1.46 & 0.03 & 0.02 & 0.02 & 0.08 \\
\hline SE3 & $4.74 \pm 0.7$ & $8.53 \pm 1.07$ & $180 \pm 7.77$ & $15.27 \pm 0.82$ & 0.55 & 1.8 & 0.05 & 0.03 & 0.019 & 0.074 \\
\hline SE4 & $4.45 \pm 0.5$ & $6.15 \pm 1.1$ & $240 \pm 7.19$ & $16.08 \pm 0.57$ & 0.72 & 1.4 & 0.026 & 0.02 & 0.02 & 0.08 \\
\hline SE5 & $4.8 \pm 1.2$ & $7.07 \pm 2.06$ & $252 \pm 12.24$ & $17.43 \pm 0.8$ & 0.7 & 1.5 & 0.03 & 0.02 & 0.021 & 0.085 \\
\hline SE6 & $5.07 \pm 1.6$ & $9.23 \pm 1.42$ & $252 \pm 8.2$ & $18.9 \pm 1.03$ & 0.55 & 1.82 & 0.04 & 0.02 & 0.023 & 0.092 \\
\hline SE7 & $4.18 \pm 0.35$ & $8 \pm 2.07$ & $227 \pm 7.29$ & $16.65 \pm 0.73$ & 0.52 & 1.91 & 0.035 & 0.02 & 0.02 & 0.081 \\
\hline SE8 & $5.72 \pm 2.15$ & $5.61 \pm 1.7$ & $232 \pm 3.77$ & $15.92 \pm 0.67$ & 1.01 & 1 & 0.024 & 0.024 & 0.02 & 0.08 \\
\hline SE9 & $4.6 \pm 0.71$ & $7.76 \pm 2.07$ & $291 \pm 11.6$ & $19.35 \pm 1.03$ & 0.6 & 1.7 & 0.026 & 0.015 & 0.023 & 0.094 \\
\hline SE10 & $4.51 \pm 1.6$ & $6.23 \pm 2.5$ & $223 \pm 4.04$ & $15.44 \pm 0.44$ & 0.72 & 1.4 & 0.03 & 0.02 & 0.02 & 0.075 \\
\hline SE11 & $3.91 \pm 0.44$ & $10 \pm 1.7$ & $223 \pm 11.08$ & $17.69 \pm 1.2$ & 0.4 & 2.56 & 0.045 & 0.02 & 0.021 & 0.086 \\
\hline SE12 & $5.07 \pm 1.15$ & $10.76 \pm 2.13$ & $202 \pm 11.82$ & $17.82 \pm 1.39$ & 0.5 & 2.12 & 0.053 & 0.025 & 0.022 & 0.09 \\
\hline SE13 & $5.04 \pm 1.43$ & $6.54 \pm 1.02$ & $257 \pm 5.83$ & $17.30 \pm 0.66$ & 0.77 & 1.3 & 0.025 & 0.02 & 0.021 & 0.084 \\
\hline SE14 & $5.34 \pm 2.12$ & $6.54 \pm 2.5$ & $277 \pm 6.63$ & $18.27 \pm 0.72$ & 0.81 & 1.3 & 0.024 & 0.02 & 0.022 & 0.09 \\
\hline SE15 & $5 \pm 1.6$ & $6.77 \pm 1.5$ & $239 \pm 6$ & $16.68 \pm 0.64$ & 0.74 & 1.35 & 0.03 & 0.02 & 0.02 & 0.081 \\
\hline SW1 & $5.5 \pm 2.32$ & $6.92 \pm 2.06$ & $257 \pm 5.31$ & $17.75 \pm 0.75$ & 0.8 & 1.25 & 0.027 & 0.021 & 0.022 & 0.087 \\
\hline SW2 & $3.32 \pm 1.1$ & $8.46 \pm 1.18$ & $242 \pm 7.74$ & $17.22 \pm 0.79$ & 0.4 & 2.54 & 0.035 & 0.013 & 0.021 & 0.084 \\
\hline SW3 & $4 \pm 1.2$ & $8.46 \pm 1.3$ & $267 \pm 9.68$ & $18.56 \pm 0.95$ & 0.5 & 2.11 & 0.032 & 0.015 & 0.023 & 0.091 \\
\hline SW4 & $5.64 \pm 2.19$ & $7 \pm 2$ & $237 \pm 3.87$ & $17.03 \pm 0.81$ & 0.8 & 1.24 & 0.03 & 0.024 & 0.02 & 0.083 \\
\hline SW5 & $4.5 \pm 1.45$ & $7.7 \pm 1.15$ & $197.5 \pm 4.77$ & $15.35 \pm 0.67$ & 0.6 & 1.71 & 0.04 & 0.022 & 0.018 & 0.075 \\
\hline SW6 & $4.8 \pm 2.1$ & $8.5 \pm 1.3$ & $208 \pm 5.31$ & $16.45 \pm 0.83$ & 0.6 & 1.77 & 0.04 & 0.023 & 0.02 & 0.08 \\
\hline SW7 & $5.34 \pm 2.8$ & $7.7 \pm 2.15$ & $247 \pm 6.82$ & $17.8 \pm 0.85$ & 0.7 & 1.44 & 0.031 & 0.022 & 0.022 & 0.087 \\
\hline SW8 & $5.46 \pm 1.2$ & $9 \pm 1.3$ & $208 \pm 5.31$ & $17.06 \pm 0.71$ & 0.6 & 1.64 & 0.043 & 0.026 & 0.02 & 0.084 \\
\hline SW9 & $4.15 \pm 1.97$ & $7.7 \pm 1.08$ & $210 \pm 7.17$ & $15.72 \pm 0.91$ & 0.54 & 1.85 & 0.04 & 0.02 & 0.02 & 0.077 \\
\hline SW10 & $6.3 \pm 2.1$ & $7.7 \pm 1.2$ & $222 \pm 2.65$ & $17.15 \pm 0.6$ & 0.82 & 1.22 & 0.034 & 0.03 & 0.021 & 0.084 \\
\hline SW11 & $4.24 \pm 1.97$ & $6.92 \pm 2$ & $263 \pm 5.31$ & $17.47 \pm 0.7$ & 0.61 & 1.63 & 0.026 & 0.016 & 0.021 & 0.086 \\
\hline SW12 & $4.6 \pm 2.1$ & $6.92 \pm 2.1$ & $232.6 \pm 7.44$ & $16.35 \pm 0.9$ & 0.66 & 1.5 & 0.03 & 0.02 & 0.02 & 0.08 \\
\hline SW13 & $4 \pm 1.2$ & $8 \pm 1.2$ & $204 \pm 6.29$ & $15.6 \pm 0.62$ & 0.5 & 2 & 0.04 & 0.02 & 0.02 & 0.076 \\
\hline SW14 & $4.5 \pm 1.45$ & $9.23 \pm 1.14$ & $217 \pm 8.78$ & $17.19 \pm 0.86$ & 0.48 & 2.05 & 0.042 & 0.02 & 0.021 & 0.084 \\
\hline SW15 & $4 \pm 1.2$ & $8.61 \pm 1.4$ & $258 \pm 10.68$ & $18.28 \pm 1.02$ & 0.46 & 2.15 & 0.033 & 0.015 & 0.022 & 0.09 \\
\hline Average & $4.6 \pm 1.54$ & $7.86 \pm 1.705$ & $235.8 \pm 7.185$ & $17.175 \pm 0.83$ & 0.602 & 1.69 & 0.0345 & 0.0205 & 0.0216 & 0.0835 \\
\hline Stand. Dev. & 9.22 & 6.23 & 200.21 & 7.3 & 1.34 & 0.58 & 0.03 & 0.05 & 0.04 & 0.46 \\
\hline Max. & 6.3 & 10.76 & 291 & 21.07 & 1.01 & 2.56 & 0.053 & 0.026 & 0.026 & 0.01 \\
\hline Min. & 3.32 & 5.61 & 180 & 15.27 & 0.4 & 1 & 0.024 & 0.015 & 0.018 & 0.074 \\
\hline
\end{tabular}




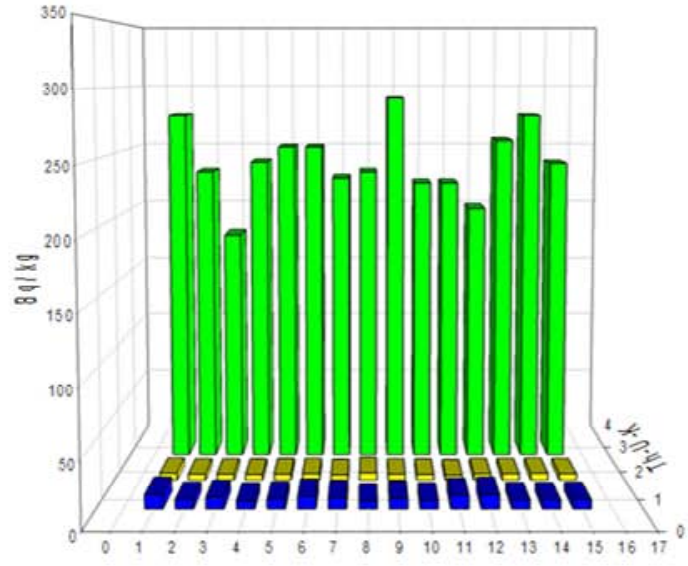

SE

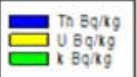

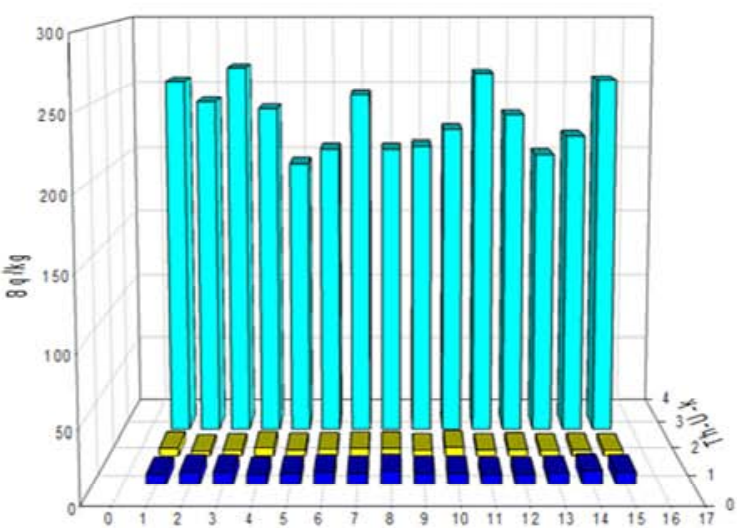

sw

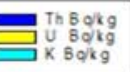

Figure 6. ${ }^{238} \mathrm{U},{ }^{232}$ Th and ${ }^{40} \mathrm{~K}$ concentrations $\left(B q \mathrm{~kg}^{-1}\right)$ in the east and west coasts of the Nile River soil samples.

Table 7. Comparison data between the present study ranges of the measured ${ }^{238} U,{ }^{232} \mathrm{Th}$ and ${ }^{40} \mathrm{~K}$ in the two sections with the other national and international Soil and Sediments samples data.

\begin{tabular}{lllll}
\hline Location Reference & ${ }^{238} \mathbf{U}$ & ${ }^{232} \mathbf{T h}$ & ${ }^{40} \mathbf{K}$ & \\
\hline Present study ranges & & & & \\
\hline SE & $3.91 \pm 0.44 \sim 5.72 \pm 2.15$ & $5.61 \pm 1.7 \sim 10.76 \pm 1.93$ & $180 \pm 7.77 \sim 291 \pm 11.6$ & \\
SW & $3.32 \pm 1.1 \sim 6.3 \pm 2.1$ & $6.92 \pm 2.06 \sim 9 \pm 1.3$ & $197.5 \pm 4.77 \sim 267 \pm 9.68$ & Shaban et al. (2008) \\
Upper Egypt soil & - & $12.5 \pm 1.7$ & $224 \pm 13$ & Ibrahiem et al. (1993) \\
Nile Delta and Middle Egypt sediments & & & & Ibrahiem et al. (1993) \\
Clay loam silt & 15.5 & 17.9 & 317 & El-Tahawy et al. (2001) \\
Sandy loam & 14.8 & 15.5 & 288.6 & El-Tahawy et al. (2001) \\
Nile Estuaries & & & & Bikit et al. (2006) \\
$\begin{array}{l}\text { Damietta Eastern shore sediments } \\
\text { Damietta Western shore sediments }\end{array}$ & 193.2 & 267.4 & & Bikit et al. (2006) \\
$\begin{array}{l}\text { Other rivers } \\
\text { Danube River, Bezdan, Serbia }\end{array}$ & $31 \pm 6$ & $2.9-12.7$ & $395 \pm 17$ & Bikit et al. \\
$\begin{array}{l}\text { Danube River, Petrovaradin, Serbia } \\
\text { Danube River, Novi Sad (2006) }\end{array}$ & $34 \pm 10$ & $26 \pm 4$ & $430 \pm 40$ & Cukrov and Bariši'c (2006) \\
Krka River, Croatia & $25 \pm 6$ & $34 \pm 4$ & $331 \pm 23$ & Yeager et al. (2002) \\
Loco Bayon basin & & $23 \pm 3$ & $18-45$ &
\end{tabular}

Table 8. Natural radionuclide content in soil Data not referenced are from UNSCEAR 2000 Survey of Natural Radiation Exposures.

\begin{tabular}{lllllll}
\hline Region / country & \multicolumn{2}{l}{ Concentration in soil $\left(\mathbf{B q k g}^{-1}\right)$} & & & \\
\hline & ${ }^{\mathbf{4 0}} \mathbf{K}$ & & ${ }^{238} \mathbf{U}$ & & \\
\hline Africa & Mean & Range & Mean & Range & Mean \\
\hline Algeria & 370 & $66-1150$ & 30 & $2-110$ & 25 & Range \\
Egypt & 320 & $29-650$ & 37 & $6-140$ & 20 & 18 \\
\hline
\end{tabular}

Table 9. External exposure rates calculated from various concentrations of terrestrial radionuclides in soil.

\begin{tabular}{|c|c|c|c|c|c|}
\hline \multirow[t]{2}{*}{ Radionuclide } & \multicolumn{2}{|c|}{ Concentration in soil $\left(\mathrm{Bqkg}^{-1}\right)$} & \multirow{2}{*}{$\begin{array}{l}\text { Dose coefficient [I20, } \\
\left.\mathrm{S}^{2} 9\right]\left(\mathrm{nGyh}^{-1} \text { per } \mathrm{Bqkg}^{-1}\right)\end{array}$} & \multicolumn{2}{|c|}{ Absorbed dose rate in air $\left(\mathrm{nGyh}^{-1}\right)$} \\
\hline & Median value & Population-weighted value & & Median value & Population-weighted value \\
\hline${ }^{40} \mathrm{~K}$ & 400 & 420 & 0.0417 & 17 & 18 \\
\hline${ }^{238} \mathrm{U}$ & 35 & 33 & 0.462 & 16 & 15 \\
\hline${ }^{232} \mathrm{Th}$ & 30 & 45 & 0.604 & 18 & 27 \\
\hline Total & & & & 51 & 60 \\
\hline
\end{tabular}


Table 10. External exposure rates from terrestrial gamma radiation Data not referenced are from UNSCEAR Survey of Natural Radiation Exposures (UNSCEAR2000).

\begin{tabular}{|c|c|c|c|c|c|}
\hline \multirow{2}{*}{ Region / country } & \multirow{3}{*}{ Population in $1996\left(10^{6}\right)$} & \multicolumn{4}{|c|}{ Absorbed dose rate in air $\left(\mathrm{nGyh}^{-1}\right)$} \\
\hline & & \multicolumn{2}{|l|}{ Outdoors } & \multicolumn{2}{|l|}{ Indoors } \\
\hline Africa & & Average & Range & Average & Range \\
\hline Algeria [B4] & 28.78 & 70 & 20- 133 & & 14-2 100 \\
\hline Egypt [H9, I13] & 63.27 & 32 & 8- 93 & & \\
\hline Namibia [S12] & 1.58 & & & & \\
\hline Sudan & 27.29 & 53 & $26-690$ & & \\
\hline
\end{tabular}

The study area was divided into two sections along the East and West banks of the River Nile.

Table 6 summarizes the activity concentration ranges for the radionuclides under considerations in each section.

A. The first section: the East bank of the Nile River

The first section is extended from station SE1 to SE15 as listed in Table 6. This section includes the highest and lowest concentration values of ${ }^{232} \mathrm{Th}$ on the whole study area. Relatively high level of ${ }^{238} \mathrm{U}$ concentration has been observed at SE8. This is could be due to the soil type. Irregular spatial distribution has been observed for ${ }^{238} \mathrm{U}$ and ${ }^{232} \mathrm{Th}$ radioisotopes.

The first section was characterized by wide ranges of ${ }^{238} \mathrm{U}$ and ${ }^{232} \mathrm{Th}$; from $3.91 \pm 0.44$ to $5.72 \pm 2.15 \mathrm{Bqkg}^{-1}$ with average $4.5 \pm 1.23 \mathrm{Bqkg}^{-1}$, and from $5.61 \pm 1.7$ to $10.76 \pm 1.93 \mathrm{Bqkg}^{-1}$ with average $7.8 \pm 1.99 \mathrm{Bqkg}^{-1}$ 'respectively'.

Decline trends of ${ }^{40} \mathrm{~K}$ values were observed in the first at SE3 and second sections SW5 as shown in Figure 6

The first section showed the decline trend of ${ }^{40} \mathrm{~K}$ values decreasing from SE9 (291 $\left.\mathrm{Bqkg}^{-1}\right)$ to

SE3 (180Bq kg-1).

This could be due to the change of the soil type with the increase of the river flow.

B. The second section: the West bank of the Nile River

This section is extended from station SW1 to SW15 as listed in Table 6.

Relatively high level of ${ }^{238} \mathrm{U}$ concentration has been observed at SW10. This is could be due to the presence of phosphate fertilizers in the soil because it is an agricultural area.

This section was characterized by irregular distribution patterns for ${ }^{238} \mathrm{U},{ }^{232} \mathrm{Th}$ and ${ }^{40} \mathrm{~K}$ radioisotopes.

The second section was characterized by wide ranges of ${ }^{238} \mathrm{U}$ and ${ }^{232} \mathrm{Th}$; from $3.32 \pm 1.1$ to $6.3 \pm 2.1 \mathrm{Bqkg}^{-1}$ with average $4.7 \pm 1.85 \mathrm{Bqkg}^{-1}$, and from $6.92 \pm 2$ to $9 \pm 1.3 \mathrm{Bqkg}^{-1}$ with average $7.92 \pm 1.42 \mathrm{Bqkg}^{-1}$ 'respectively'.

The second section showed the decline trend of ${ }^{40} \mathrm{~K}$ values decreasing from SW3 (267 $\mathrm{Bqkg}^{-1}$ ) to SW5 (197.5 $\mathrm{Bqkg}^{-1}$ ).

This could be due to the change of the soil type with the increase of the river flow. The confluence of two Niles (blue and white Niles) play an important role for increase the levels of ${ }^{238} \mathrm{U}$ and ${ }^{232} \mathrm{Th}$ due to the erosion processes.

C. Effective factors: Many factors could be distinguished to play an effective role in the distribution of the detected natural radioisotopes along the study area. The First and the most important that the presence of fertilizers in the soil because it is an agricultural area. The Second factor the soil types. Thirdly could be the locations of the soil sample. The samples collected along the East and West banks of the Nile River.

The other factor could be due to the human activities and its corresponding waste. Moreover, the contamination from the drainage of fertilizers hold radioactive materials, the mineralogical of the sites such as the presence of calcium carbonate and the chemistry of the Nile water could be added as another factors controlling the distribution of the radioisotopes under consideration.

The geographical features of the Nile are also considered as important factors controlling the distribution of the radioactive isotopes under consideration. Radioactive materials could be transported with the flow of the Nile water from the central Africa and Ethiopia such as the black sand, which is characterized by relatively high radioactivity concentrations [14]; [13].

The other factor erosion processes can play important role to remove the upper light sediments layer and expose the old soils, which contains black sand.

Table 7 shows the concentration ranges obtained from each section compared with the other referenced values. The detected ranges of ${ }^{238} \mathrm{U}$ and ${ }^{232} \mathrm{Th}$ are in agreement with the other referenced data for the other parts of Nile River [16]; [18]; [14]; [17]; [20].

\subsection{Absorbed Dose Rate (DR)}

The absorbed dose rates due to gamma radiations in air at $1 \mathrm{~m}$ above the ground surface for the uniform distribution of the naturally occurring radionuclides $\left({ }^{238} \mathrm{U},{ }^{232} \mathrm{Th}\right.$ and $\left.{ }^{40} \mathrm{~K}\right)$ were calculated which based on the guidelines provided by UNSCEAR [11]. The conversion factors used to compute the absorbed gamma dose rate (DR) in air per unit activity concentration in $\mathrm{Bqkg}^{-1}$ (dry weight) corresponds to 0.428 $\mathrm{nGyh}^{-1}$ for ${ }^{238} \mathrm{U}, 0.666 \mathrm{nGyh}^{-1}$ for ${ }^{232} \mathrm{Th}$ and $0.042 \mathrm{nGyh}^{-1}$ for ${ }^{40} \mathrm{~K}$. Therefore DR can be calculated as follows:

$$
\mathrm{DR}\left(\mathrm{nGyh}^{-1}\right)=0.428 \mathrm{~A}_{\mathrm{U}}+0.666 \mathrm{~A}_{\mathrm{Th}}+0.042 \mathrm{~A}_{\mathrm{K}}
$$

Table 6 shows the absorbed dose rates calculated from ${ }^{238} \mathrm{U},{ }^{232} \mathrm{Th}$ and ${ }^{40} \mathrm{~K}$ activity concentrations for each location based on the conversion factors given by [20]. The range of the total absorbed dose rates was from at East side $15.27 \pm 0.82 \sim 21.07 \pm 1.53 \mathrm{nGyh}^{-1}$ with average $17.35 \pm 0.86$ $\mathrm{nGyh}^{-1}$.

$$
\text { At West said } 15.35 \pm 0.67 \sim 18.56 \pm 0.95 \mathrm{nGyh}^{-1} \text { with }
$$


average $17 \pm 0.8 \mathrm{nGyh}^{-1}$. The lowest values for the absorbed dose rate due to natural radionuclides were detected for sandy soil.

The population-weighted average is $84 \mathrm{nGyh}^{-1}$ with national averages ranging from 20 to $200 \mathrm{nGyh}^{-1}$. [2]

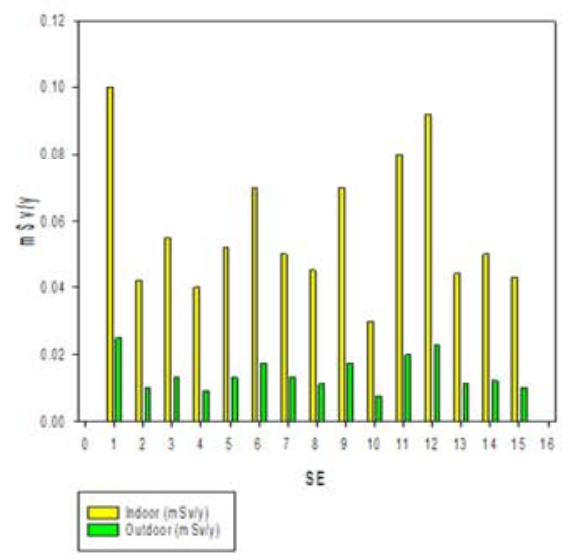

Figure 7. The contribution of the annual effective dose rate (AEDR) for the east and west banks of the Nile river soil (indoor) (outdoor)

\subsection{Annual Effective Dose Rate (AEDR)}

The annual effective dose rate (AEDR) in $\mathrm{mSvy}^{-1}$ resulting from the absorbed dose values (DR) was calculated using the following formula. The annual effective dose (Table 6) ranged between at East side (outdoor) $0.019 \sim 0.026 \mathrm{mSvy}^{-1}$ (indoor) $0.074 \sim 0.1 \mathrm{mSvy}^{-1}$. And at west side (outdoor) $0.018 \sim$ $0.023 \mathrm{mSvy}^{-1}$ (indoor) $0.075 \sim 0.091 \mathrm{mSvy}^{-1}$ with a mean value of $0.04 \mathrm{mSvy}^{-1}$. In normal background areas, the average annual indoor effective dose from terrestrial radionuclides is $0.46 \mathrm{mSvy}^{-1}$. Therefore, the obtained mean value from this study $\left(0.052 \mathrm{mSvy}^{-1}\right)$ is lower than the world average value.

Ann. Eff. dose $\operatorname{rate}\left(\mathrm{mSvy}^{-1}\right)=\mathrm{DR}\left(\mathrm{nGyh}^{-1}\right) \times 8760 \mathrm{~h} \mathrm{y}^{-1} \times$ $0.7 \times 10^{3} \mathrm{mSv} / 10^{9} \mathrm{nGy} \times 0.2$ (outdoor)

$$
\mathrm{AEDR}=\mathrm{DR} \times 1.2264 \times 10^{-3} \text { [2] (outdoor) }
$$

Ann. Eff. dose $\operatorname{rate}\left(\mathrm{mSvy}^{-1}\right)=\mathrm{DR}\left(\mathrm{nGyh}^{-1}\right) \times 8760 \mathrm{~h} \mathrm{y}^{-1} \times$ $0.7 \times 10^{3} \mathrm{mSv} / 10^{9} \mathrm{nGy} \times 0.8$ (indoor)

$$
\mathrm{AEDR}=\mathrm{DR} \times 4.9056 \times 10^{-3} \text { [2] (indoor) }
$$

The resulting worldwide average of the annual effective dose is $0.48 \mathrm{mSvy}^{-1}$, with the results for individual countries being generally within the $0.3-0.6 \mathrm{mSvy}^{-1}$ range Therefore the obtained mean value from this study $\left(0.052 \mathrm{mSvy}^{-1}\right)$ is lower than the world average value.

\section{4. ${ }^{238} \mathrm{U}$ and ${ }^{232}$ Th Activity Ratios}

The investigation of ${ }^{238} \mathrm{U}:{ }^{232} \mathrm{Th}$ activity ratio calculations revealed that ${ }^{232} \mathrm{Th}$ activity concentrations are seen to be on the average 1.6 times higher than the ${ }^{238} \mathrm{U}$ activity concentration in the measured at East bank of the Nile River soil and at the West bank of the Nile River the investigation of ${ }^{238} \mathrm{U}:{ }^{232} \mathrm{Th}$ activity ratio calculations revealed that ${ }^{232} \mathrm{Th}$ activity concentrations are seen to be on the average 1.7 times higher than the ${ }^{238} \mathrm{U}$ activity concentration.

SE8 showed the highest U/Th ratio (1.01).
The values are decreased according to the fractional utilization of the materials. This could be due to the spatial variations of minerals holding in the soil.

All the samples exhibit dose rates that range from 15 to 21 $\mathrm{nGyh}^{-1}$.

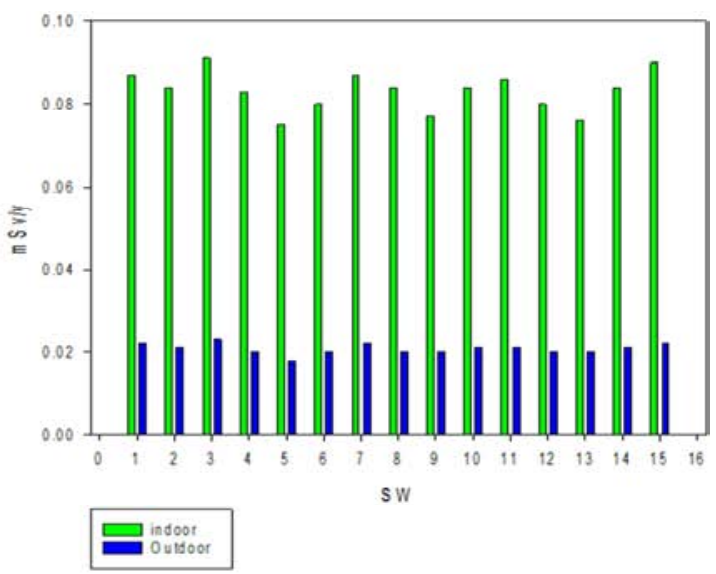

This indicated that relatively equal amount of ${ }^{238} \mathrm{U}(5.72$ $\left.\mathrm{Bqkg}^{-1}\right)$ exist than ${ }^{232} \mathrm{Th}\left(5.61 \mathrm{Bqkg}^{-1}\right)$. This is could be due to the presence of the human activities and its corresponding waste. Moreover, the contamination from the drainage of fertilizers hold radioactive materials, and the soil type loamy soil at SE8 which have relatively high amount of ${ }^{238} \mathrm{U}$. On the other hand, SE11 showed the lowest U/Th ratio (0.4). This indicated that this location has ${ }^{232} \mathrm{Th}$ activity concentration $\left(10 \mathrm{Bqkg}^{-1}\right)$ higher than ${ }^{238} \mathrm{U}\left(3.91 \mathrm{Bqkg}^{-1}\right)$. At one samples (SE8), equality has been detected between ${ }^{238} \mathrm{U}$ and ${ }^{232} \mathrm{Th}$ activity concentrations. This could be due to the differences of the mineralogy of the soil type. Also, it could be due to the geological and solubility differences between ${ }^{238} \mathrm{U}$ and ${ }^{232} \mathrm{Th}$.

From the other side, $\mathrm{Th} / \mathrm{U}$ ratios have been calculated and listed in Table 6. The presence of calcium carbonate sediments could be playing an important role for depletion of the ${ }^{232} \mathrm{Th}$ relative to ${ }^{238} \mathrm{U}$ [16]. [30] have mentioned that $0.7-$ 0.4 is the typical range for igneous zircon. [31] enlarge the previously mentioned range to $0.3-2$ for xenolith zircon. All soil samples of the coasts of the Nile River have $\mathrm{Th} / \mathrm{U}$ ratio within this range. The majority of the measured samples have $\mathrm{Th} / \mathrm{U}$ ratios match with this range. This could be indicated that the present study confirmed the presence of zircon in the banks of the Nile River soil.

\section{Conclusion}

a) The detected natural radionuclides ${ }^{238} \mathrm{U},{ }^{232} \mathrm{Th}$ and ${ }^{40} \mathrm{~K}$ showed irregular distribution patterns along the study area. The investigation of the spatial distribution of the banks of the Nile soil revealed that there are many factors affecting the distribution of the natural radioisotopes in the area under consideration.

These factors could be as the following:

(1) The phosphate fertilizers contain high concentrations 
of uranium compared with other types of Fertilizers, because there is a companion uranium phosphate.

(2) the presence of fertilizers in the soil because it is an agricultural area;

(3) the geographical feature of the stream such as the confluence of two Niles; (blue and white Niles)

(4) chemistry of the Nile water

(5) human activities and its corresponding waste.

b) The significance of the current study relies on its contribution to the efforts being done to generate a radiation map for Sudan and on the targeted area, The River Nile which is of great importance due to the heavy agricultural activities involved.

c) The activity concentrations and the absorbed dose rates, due to ${ }^{238} \mathrm{U},{ }^{232} \mathrm{Th}$ and ${ }^{40} \mathrm{~K}$, and annual effective dose rate (AEDR). These values obtained from the coastal soil were less than the recommended safe and criterion limits given by UNSCEAR.

d) The activity concentration measurements showed that ${ }^{232} \mathrm{Th}$ activities are higher than ${ }^{238} \mathrm{U}$ activity concentrations by 1.4 fold along the study area.

e) The study uses Spectral HPGe detector to evaluate the activity concentrations of ${ }^{238} \mathrm{U},{ }^{232} \mathrm{Th}$ and ${ }^{40} \mathrm{~K}$ in 30 soil samples taken from the Nile east and west banks northern Khartoum. The activity concentrations may be limited to the randomly taken samples and the results may not be generalized to the whole Nile banks. More samples are needed to evaluate

f) Results of the study could serve as an important baseline radiometric data for future epidemiological studies and monitoring initiatives in the study area. The statistical methods were applied to study the relationship between all the calculated natural radionuclides

g) The Absorbed Dose Rate in Air, Effective dose rate in Air and was calculated from the activity concentrations of $\left({ }^{238} \mathrm{U}\right)$ series, ${ }^{232} \mathrm{Th}$ series and ${ }^{40} \mathrm{~K}$. All results were found to be less than world maximum values.

h) All soil samples of the banks of the Nile River have $\mathrm{Th} / \mathrm{U}$ ratio within this range $(1-2.56)$. The majority of the measured samples have $\mathrm{Th} / \mathrm{U}$ ratios match with this range. This could be indicated that the present study confirmed the presence of zircon in the coasts of the Nile River soil.

The data collected in this experiment could be used for various purposes. It could be used to determine whether or not the radiation levels in the River Nile basin pose a health hazard to the local population or to wildlife. It could also be used to determine the chemical composition of the soil, and by comparison to soil samples that are not subject to the effects of fertilizers, the effects of fertilizer on the chemical composition of soil could be determined.

\section{References}

[1] Flores OB, Estrada AM, Suarez RR, Zerquera JT, Pe'rez AH (2008) J Environ Radioact. 99:1834.

[2] UNSCEAR (2000) "United Nations Scientific Committee on the Effects of Atomic Radiation, Sources, Effects and Risks of Ionizing Radiation", New York, United Nations, 2000.

[3] Innocent AJ, Onimisi MY, Jonah SA Evaluation of naturally occurring radionuclide materials in soil samples collected from some mining sites in Zamfara State, Nigeria. British Journal of Applied Science \& Technology. 2013; 3(4): 684692.

[4] Harb S, Salahel DK, Abbady A, Mostafa M. Activity concentration for surface soil samples collected from Armant, Qena, Egypt. Proceedings of the 4th Environmental Physics Conference, Hurghada, Egypt. 2010; (4): 49-57.

[5] Mehra R, Badhan K, Sonkawade RG, Kansal S, Singh S. Analysis of terrestrial natural radionuclides in soil samples and assessment of average effective dose. Indian Journal of Pure and Applied Physics. 2010;48:805-808.

[6] Ibrahim FA, Mohammad IA. Soil radioactivity levels and radiation hazard assessment in the highlands of northern Jordan. Radiation Measurements. 2009;44:102-110.

[7] John VM, Zordan SE. Research and development methodology for recycling residues as building materials. Waste Management. 2001;21(3):213-219.

[8] Taskin H, Karavus M, Ay P, Topuzoglu A, Hindiroglu S, Karahan G. Radionuclide concentrations in soil and lifetime cancer risk due to the gamma radioactivity in Kirklareli, Turkey. Journal of Environmental Radioactivity. 2009;100:4953.

[9] Uosif, M. A. M., \Gamma-Ray Spectroscopic Analysis of Selected Samples from Nile River Sediments in Upper Egypt", Radiation Protection Dosimetry, 123, 215\{220, 2007.

[10] El-Gamal, A., Nasr, S., El-Taher, A., IStudy of the Spatial Distribution of Natural Radioactivity in Upper Egypt Nile River Sediment", Radiation Measurements, 42, 457\{465, 2007.

[11] Dawood, Y. H., Factor Controlling Uranium and Thorium Isotopic Composition of the Streambed Sediments of the River Nile, Egypt", JAKU: Earth Science, 21, 77\{103, 2010.

[12] Bridge, J. S., 2002. In: Malden, M. A. (Ed.), Rivers and Flood Plains: Forms, Processes and Sedimentary Records. Blackwell, Oxford.

[13] El-Gamal, A., Saleh, I., Nasr, S., Naim, M., 2006. Radiological assessment of the Egyptian Mediterranean coast. In: Isotopes in Environmental Studies, Aquatic Forum 2004, Proceedings of an International Conference held in Monaco, 25-29 October, 2004 organized by IAEA, IAEA-CN-118/31P, pp. 290-291

[14] El-Tahawy, M. S., El-Moafy, W., Higgy, R., 2001. Radiological investigation of the East Nile estuary to the Mediterranean Sea. In: Ocean/atmosphere

[15] Ibrahiem, N. M., Abd ElGhani, A. H., Shawky, S. M., Ashraf, E. M., Farouk, M. A., 1993. Measurement of radioactivity levels in soil in the Nile Delta and Middle Egypt. Health Phys. 64 (6), 620-627.

[16] Khater, A. E., Ebaid, Y. Y., El-Mongy, S. A., 2005. Distribution Pattern of Natural Radionuclides in Lake Nasser Bottom Sediments, International Congress Series, vol. 1276, pp. 405-406. 
[17] Ismail, S. S., Unfried, E., Grass, F., 1994. Distribution of 137Cs and 228Ra in the sediments of Aswan High Dam Lake. J. Radioanalytical Nucl. Chem. 186 (2), 143-155.

[18] NCRP, 1976. Environmental radiation measurement, recommendations of the National Council of Radiation Protection and Measurements, NCRP Report No. 50.

[19] Saleh, I., El-Gamal, A., Nasr, S., Naim, M., 2006. Spatial and temporal variations of uranium and thorium series along the Egyptian Mediterranean coast. In: Isotopes in Environmental Studies, Aquatic Forum 2004, Proceedings of an International Conference Held in Monaco, 25-29 October, 2004 organized by IAEA, IAEA-CN-118/113P, pp. 452-454.

[20] Yu, K. N., Guan, Z. J., Stocks, M. J., Young, E. C., 1992. The assessment of natural radiation dose in Egyptian population from radiocontaminated food after Chernobyl accident. In: ElRaey, E. (Ed.), Regional Symposium on Environmental Studies (UNAR). Alexandria, Egypt

[21] Shaban Ramadan Mohamed HARB -Khaled SALAHEL DIN -Abd Elbaset ABBADY-Mohamed Abd Elleh ALI Rolf MICHEL- Measurements of natural radionuclides in soil samples from Upper Egypt (2008)

[22] Bikit, I., Slivka, J., Veskovi'c, M., Varga, E., Žiki'cTodorovi'c, N., MrYa, D., Forkapi'c, S., 2006. Measurement of Danube sediment radioactivity in Serbia and Montenegro using gamma ray spectrometry. Radiat. Meas. 41, 477-481.

[23] Degens, E., Kempe, S., Richey, J. E., 1991. Biogeochemistry of major world rivers-Scientific Committee on Problems of the Environment, SCOPE-42.

[24] Biogeochemical Coupling Symposium, organized by the International Association for the Physical Sciences of the Oceans (IAPSO), IM01-15.

[25] IAEA, 1989. Measurement of radionuclides in food and the environment. A guidebook. Technical Reports Series No. 229, Vienna

[26] Nordic, 2000. Naturally occurring radioactivity in the Nordic countries - recommendations, ISBN, 91-89230-00-0.

[27] Durrance, E. M., 1986. Radioactivity in Geology, Principles and Applications. Ellis Horwood Limited, Chichester, UK.

[28] UNSCEAR Exposure from natural radiation sources, AnnexB. Sources and effects of ionizing radiation 2000

[29] UNSCEAR, "Sources and Effects of Ionizing Radiation", Report to General Assembly, with Scientific Annexes, United Nation, New York. (2000).

[30] Mitchell, G., Mihalynuk, L., Heaman, L. M., 2001. Age of Mineralized Porphyry at the Logtung deposit W-Mo-Bi-Be (Beryl, Aquamarine), Northwest BC, British Columbia Geological Survey, Geological Fieldwork 2001, Paper 2002-1, pp. 35-40.

[31] Vazquez, J. A., Shamberger, P. J., Hammer, J. E., 2005. Timing of extreme magmatic differentiation at Hualalai and Mauna Kea volcanoes from ${ }^{238} \mathrm{U},{ }^{230} \mathrm{Th}$ and $\mathrm{U}-\mathrm{Pb}$ dating of zircons from plutonic xenoliths. In: AGU Fall Meeting, 5-9 December, 2000, Moscone Center West, San Francisco, CA, USA.
[32] International Basic Safety Standards for Protection Against Ionizing Radiation and for the Safety of Radiation Sources. 115, Safety Standards. IAEA, February 1996.

[33] International BSS for protection against ionizing radiation and for safety of radiation sources. 115 safety standards, IAEA.

[34] Measurement of some natural radionuclide in Elgash area (Sudan). Babiker AliA/ Rahma Mustafa M. OAhmed, Elameen and Adam KSam. University of Kasala, University of Khartoum and Sudan Atomic Energy Commission (SAEC).

[35] Nuclear radiation and its biological effects recommendation 1999. Radiation exposure map based on fuzzy logic for the representation ofArea with high natural background, International Nuclear Atlantic conference-INAC 2009 Rio de janeiro, RJ, Brazil, September 27 to october 2,2009.

[36] Radioactivity Levels in The Red Sea Costal Environment Of Sudan.. Adam K Sam, Mustafa M. O Ahmed, F. A. Alghangi.. Elis Holm. SAEC. University of Khartoum. radiation physics department Lund Sewden.

[37] The national radioactivity in phosphate depositsfrom Sudan. Adam K Sam, Elis Holm United Nation Source and Effects Of Ionizing Radiation. United Nations Scientific Committee On The Effects Of Atomic Radiation, 1993.

[38] A. MUmber, M. Y. Onimisi and S. A. Jonah Baseline Measurement of Natural Radioactive in Soil, Vegetation and Water in Industrial District of theFederial CapitalTerritory (FCT) Abuja, Nigeria.

[39] Sarata Kumar SAHOO, Masah HOSODA, Sadatoshi KAMAGATA, Atsuyuki SORIMACHI, Tetsuo ISHIKAWA, Shinji TOKONAMI, Shigeo UCHIDA Thorium, Uranium and Rare Earth Elements Concentration in Weathered Japanese soil samples. Research Center for Radiation Protection, Natural Institute of Radiology Sciences, 4-9 Angawa, Inage$\mathrm{Ku}$, Chiba, 263- 8555, Japan

[40] Abdullahi, M. A., Mohammed, S. S. and Iheakanwa, I. A. Measurement of Natural Radioactivity in Soil Along the Bank of River Kaduua -Nigeria. Department of Applied Sciences of Science and Technology Kaduuna polytechnic, KadunaNIGERIA www.ajer.org

[41] W. R ALHARBI, J. H HLZARANI and ADEL G. E ABBADY Assessment of Radiation Hazard indices from Granite rocks of the southeastern Arabian shield, Kingdom of Saudi Arabia. Australian Journal of Basic and Applied Sciences, 5(6): 672682, 2011 ISSN 1991-8178.

[42] Michal Tzortzis and HaralabosTsertos Dept. of Physics, U. of Cyprus, Nicosia Stelios Christofides and George Christodoulides Medical Physics Dept, Nicosia General Hospital, Nicosia, Cyprus Gamma - ray measurement of natural occurring radioactive Samples from Cyprus characteristic geological rocks.

[43] Dr. Kenneth H. Rubin, Department of Geology and Geophysics School of Ocean and Erath Sciences and Technology University of Hawaii 1680 East West Rd. Honolulu Hi 96822

[44] International Atomic Energy Agency (IAEA), soil sampling for environmental contaminants. IAEA-TECDOC-1415. 2004, Vinna: IAEA. 